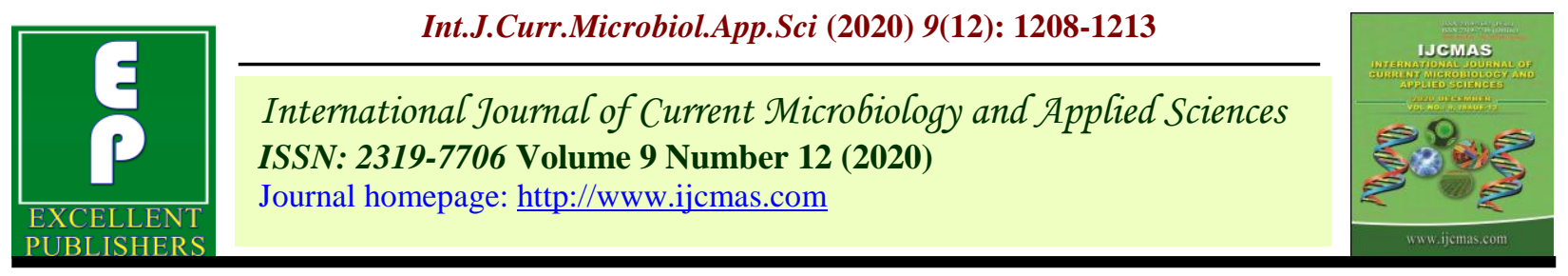

Original Research Article

https://doi.org/10.20546/ijcmas.2020.912.148

\title{
Impact of Variety and Date of Showing on Growth Performance of Bt-Cotton in Middle Gujarat Conditions
}

\author{
Vibha Tak*, Vyas Pandey and P.K. Parmar \\ Department of Agricultural Meteorology, B. A. College of Agriculture, Anand Agricultural \\ University, Anand - 388110, India \\ *Corresponding author
}

\begin{tabular}{l} 
K e y w o r d s \\
$\begin{array}{l}\text { Bt-cotton, Showing } \\
\text { dates, Variety, } \\
\text { growth, Biomass, } \\
\text { etc. }\end{array}$ \\
\hline Article Info \\
$\begin{array}{l}\text { Accepted: } \\
10 \text { November } 2020 \\
\text { Available Online: } \\
10 \text { December } 2020\end{array}$ \\
\hline
\end{tabular}

\section{A B S T R A C T}

A field experiment was conducted during the kharif season of the year 2012 at Agronomy farm of B. A. College of Agriculture in a split plot design with two Bt-cotton cultivars viz. Vikram-5 $\left(\mathrm{V}_{1}\right)$ and $\mathrm{RCH}-2\left(\mathrm{~V}_{2}\right)$ as a main plot treatment and three dates of sowing 25thMay $\left(\mathrm{D}_{1}\right)$, 10thJune $\left(\mathrm{D}_{2}\right)$ and $25^{\text {th }}$ June $\left(\mathrm{D}_{3}\right)$ as sub-plot treatment with four replications. Three dates of sowing provided three different environments in terms of thermal and moisture regimes. The results indicated that the total crop duration varied with the dates of sowing. The crop life period was found to be shortened with delay in sowing, more pronounced being in cv. Vikram-5. The total biomass yield of cotton as influenced by different treatments showed that the first date of sowing $\left(D_{1}\right)$ had produced significantly higher seed cotton yield as well as total biomass.

\section{Introduction}

Cotton is an important fibre yielding crop of global importance, which is grown in tropical and subtropical regions of more than 80 countries world over. Cotton refers to those species of the genus Gossypium, which bear spinnable seed coat fibres. Cotton is grown chiefly for its fiber used in the manufacture of cloth for the mankind. It is also used for several other purposes like making threads, for mixing in other fibers and extraction of oil from the cotton seed. The oil content in the cotton seed ranges from 15-25 percent depending of the varieties. Cotton seed cake, after extraction of oil is good organic manure and contains about $6 \%$ nitrogen, $3 \%$ phosphorus and $2 \%$ potash. Cotton seed, cotton linters and pulp obtained during oil extraction and cotton meal are good concentrated feed for cattles. Out of about 50 species of cotton plants in the world, only four have been domestically cultivated for cotton fibres. Gossypium hirsutum and Gossypium barbadense are the most commonly cultivated species of cotton in the 
world. Gossypium hirsutum variety is the most important agricultural cotton, accounting for more than $90 \%$ of world fibre production (Anon, 2013b). India is the only country, where all four cultivated species of cotton are grown on commercial scale and has one of the largest growing areas of cotton in the world with production of 33.9 million bales in the year of 2012-2013 (Anon., 2013b). India ranks first with respect to area under cotton and stands second in total production after China but the productivity is very low with $555 \mathrm{~kg} / \mathrm{ha}$ as against world average of 794 $\mathrm{kg} / \mathrm{ha}$ (Arshad et al., 2011).

Cotton is cultivated in India from subHimalayan region of Punjab in the north to Kerala in south and from dry regions of Kutch to high rainfall areas of Manipur in east. Cultivation of hybrids, Bt cotton varieties, latest production technology and plant protection technologies, adoption of scientific and agronomic practices by farmers, increase in area under irrigation, Government policies on R\&D and price support, are all responsible for the present drastic changes of Indian cotton scenario to its present position. The technology was found to be very favorable for farmers all over the world and has been responsible for tremendous reduction in the overall use of insecticides against cotton bollworms. Insect resistance, however, can reduce the effectiveness of Btcrops and is therefore a major concern for the long-term sustainability of $B t$ crops.

\section{Materials and Methods}

A field experiment was conducted during the kharif season of the year 2012 at Agronomy farm of B. A. College of Agriculture, India situated at $22^{\circ} 35^{\prime} \mathrm{N}$ latitude and $72^{\circ} 55^{\prime} \mathrm{E}$ longitude and at an altitude of $45.1 \mathrm{~m}$ above mean sea level. Experiment carried out in a split plot design with two Bt-cotton cultivars viz. Vikram-5 $\left(\mathrm{V}_{1}\right)$ and $\mathrm{RCH}-2\left(\mathrm{~V}_{2}\right)$ as a main plot treatment and three dates of sowing 25thMay $\left(\mathrm{D}_{1}\right)$, 10thJune $\left(\mathrm{D}_{2}\right)$ and 25thJune $\left(D_{3}\right)$ as sub-plot treatment with four replications. Three dates of sowing provided three different environments in terms of thermal and moisture regimes. The location of the field experiment at the research farm falls under middle Gujarat Agro-climatic Zone-III of the Gujarat State and is $90 \mathrm{~km}$ away from the Arabian Sea. Its climate has been classified as semi-arid tropical. The average annual rainfall of Anand is $839.6 \mathrm{~mm}$ and is received through Southwest monsoon wind currents during the 3rd week of June and withdraws by the 2nd week of September. The weather remains dry from October to May. Summer is hot and sometimes mercury crosses $45.0^{\circ} \mathrm{C}$ in the month of May, while winter is cool and dry and temperature drops up to $5.0^{\circ} \mathrm{C}$ during January. The soil of the experimental site is representative of the soils of the region and is popularly known as "Goradu" soil. This soil is of alluvial origin and classified as "Loamy sand" and belongs to Entisols. The experimental field had a good drainage as well as fair moisture retentive capacity.

\section{Results and Discussion}

\section{Plant height}

The plant height measured from the ground to base of apical shoot was recorded starting from 15 DAS to physiological maturity in all the treatments. The development of plant remained slow during the early vegetative growth period (45 DAS) and therefore, increased sharply with the advancement of the crop age during the kharif season in all dates of sowing. The plant height continuously increased upto 165 DAS, the highest plant height was observed inRCH-2followed by Vikram- 5 at 165 days DAS after that plant height continuously increased gradually as crop plants approaches maturity. Similar trend 
with date of sowing were observed where the lowest plant height was at 165 DAS in $\mathrm{D}_{3}$ as compared to $\mathrm{D}_{1}$ and $\mathrm{D}_{2}$ dates (Fig. $1 \mathrm{a} \& \mathrm{~b}$ ).

\section{Total dry biomass}

The plant was kept for sun drying for two to three days and thereafter kept in oven at $70^{\circ} \mathrm{C}$ constant temperature until a constant weight of dry matter was obtained. Total dry matter accumulated over the pertinent period of time was then analyzed. Among different treatments $\mathrm{D}_{1}$ (25thMay) $\mathrm{D}_{2}$ (10thJune) and $\mathrm{D}_{3}$ (10thJune) the higher biomass was recorded in $\mathrm{D}_{1}\left(25^{\text {th }}\right.$ May) date of sowing followed by $D_{2}$ and $D_{3}$. The dry matter accumulation from 75 to 120 DAS increased at correspondingly increasing rate in $\mathrm{D}_{1}, \mathrm{D}_{2}$ and $\mathrm{D}_{3}$ treatments. It was also observed that the accumulation of dry matter in $D_{1}$ was more than that of $\mathrm{D}_{2} \& \mathrm{D}_{3}$ (Fig. 2a\&b).

The development of plant remained slow during the early vegetative growth period (75 DAS) and therefore, increased sharply with the advancement of the crop age during the kharif season in all dates of sowing.Thestemdrybiomasscontinuouslyincre asedupto165DAS, the highest stem dry biomass was observed in RCH-2 $(54.3 \mathrm{~g} / \mathrm{m} 2)$ followed by Vikram- $5(39.7 \mathrm{~g} / \mathrm{m} 2)$ at 165 days DAS after that stem dry biomass continuously increased gradually as crop plants approaches maturity. Similar trend with root and leaf partitioning dry biomass were observed during crop growing season.

Fig.1(a\&b) Periodical plant height of Bt-cotton as influenced by (a) dates of sowing and (b) variety
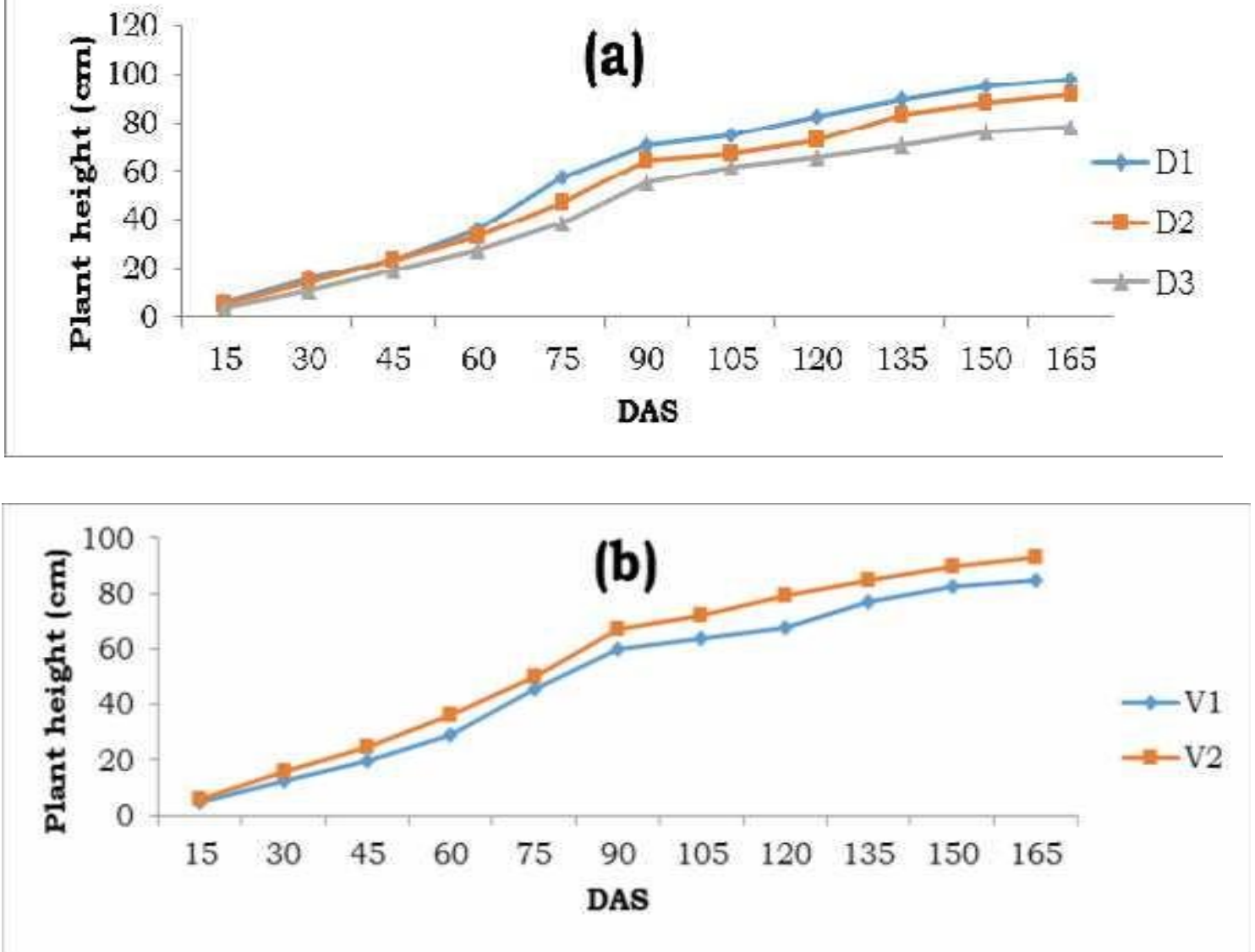
Fig.2(a\&b) Periodical total dry matter $\left(\mathrm{g} / \mathrm{m}^{2}\right)$ as influenced by (a) dates of sowing and (b) variety
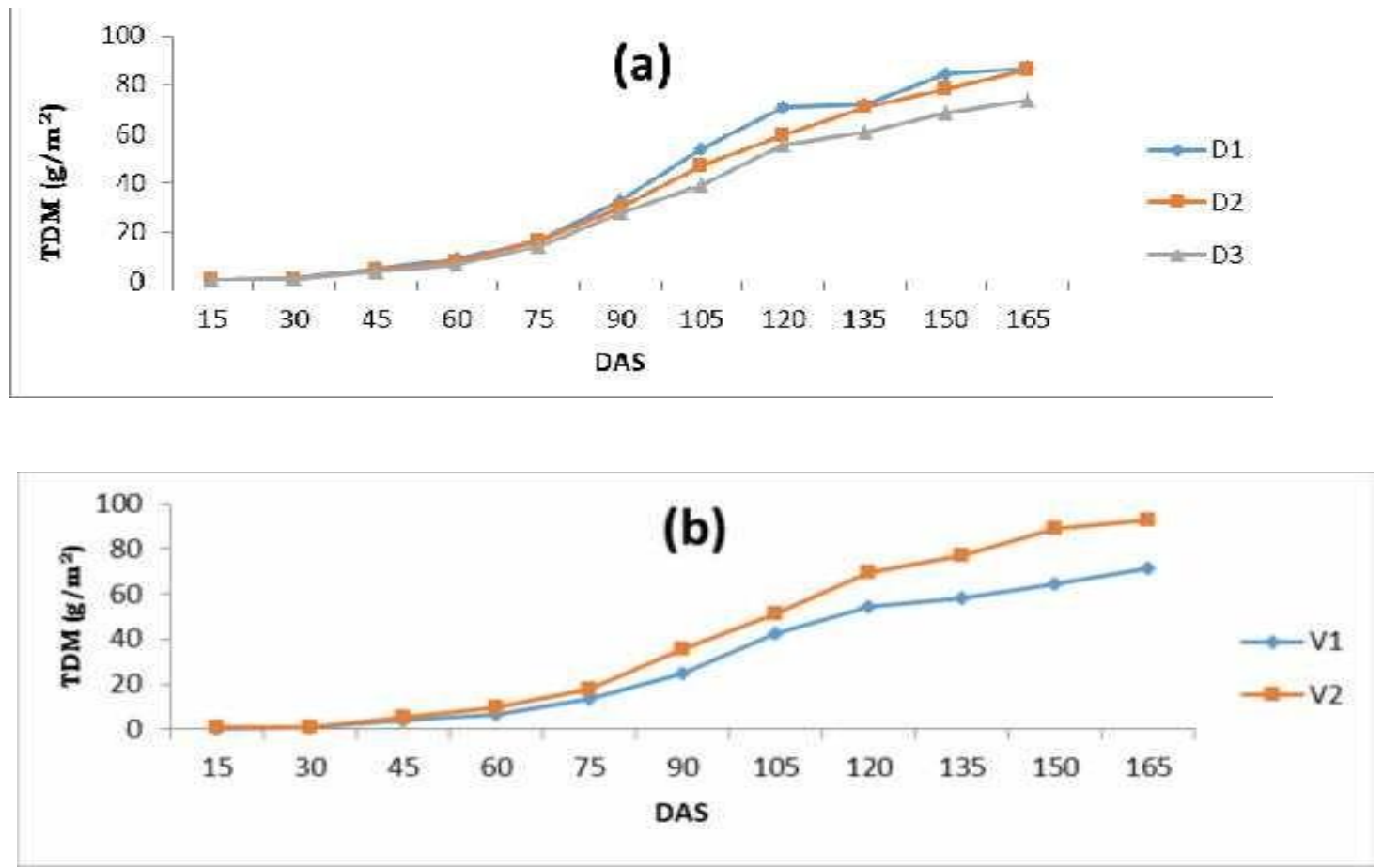

Fig.3 $\left(\mathrm{V}_{1} \& \mathrm{~V}_{2}\right)$. Partitioning of dry biomass $\left(\mathrm{g} / \mathrm{m}^{2}\right)$ in root, stem, leaf as influenced by variety

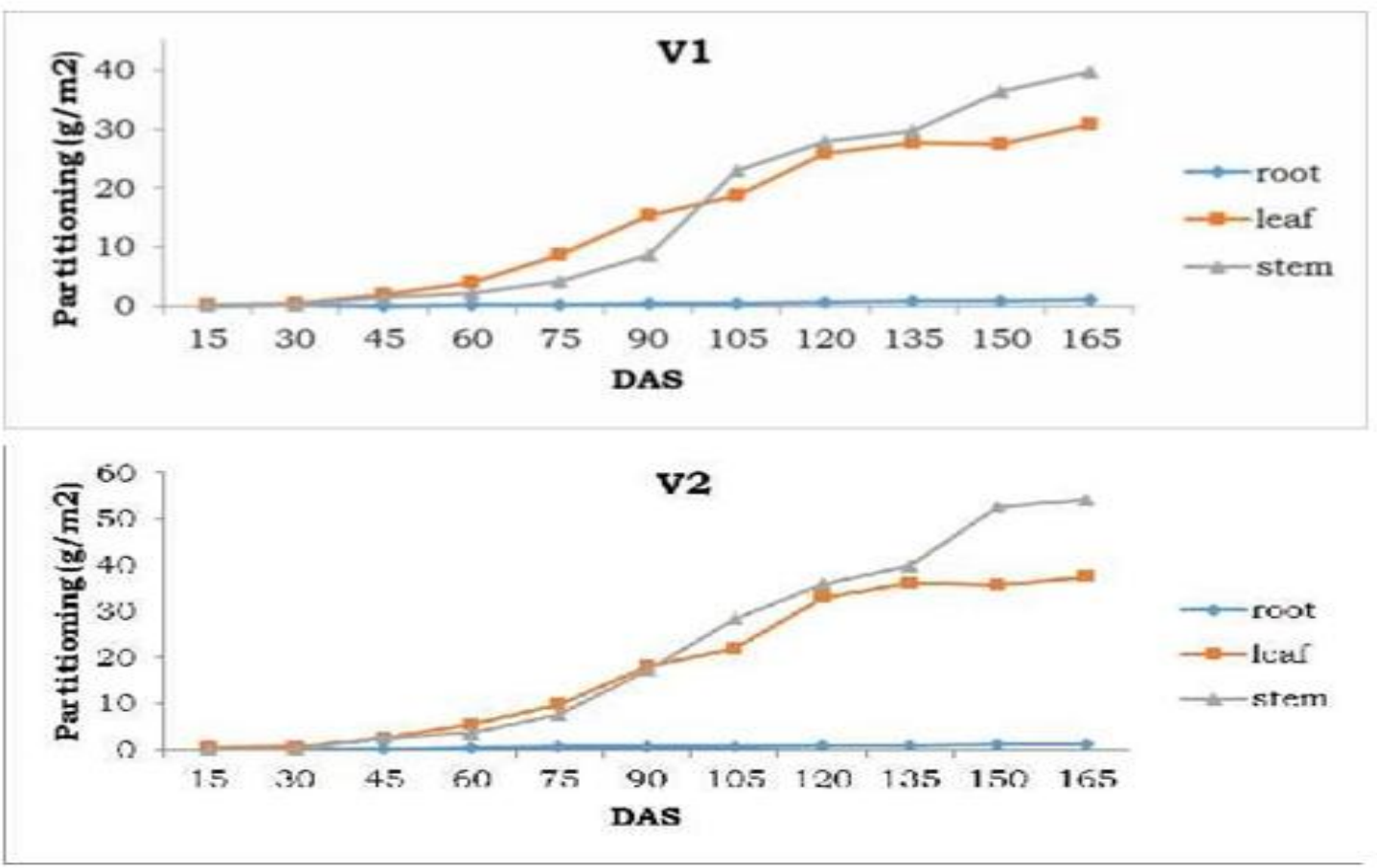


The data pertaining to plant height starting from 15 DAS to physiological maturity for two cultivars of Bt-cotton under percent portioning of root, leaf and stem of dry biomass are presented graphically in the Fig. $3\left(\mathrm{~V}_{1}\right)$ and $\left(\mathrm{V}_{2}\right)$.

In conclusion, the findings of present experiment indicated that the total crop duration varied with the dates of sowing. The crop life period was found to be shortened with delay in sowing, more pronounced being in cv. Vikram-5. The total biomass yield of cotton as influenced by different treatments showed that the first date of sowing $\left(D_{1}\right)$ had produced significantly higher seed cotton yield as well as total biomass.

\section{References}

Akhtar, M., Chima, M. S., Moazzam Jamil, Shahid Shaukat Ali and Shahid I., (2002). Response of cotton genotypes to time of sowing. Asian Journal of Plant Sciences., 1 (5): 538-539.

Ansari, M. D. Shahim and Mahey, R.K., (2003). Growth and yield of cotton species as affected by sowing dates and nitrogen levels. Journal of Research Punjab Agriculture University, 40 (1): 8-11.

Anuradha, N. and Reddy, A. R. (2011). Analysis of Growth and Instability of cotton production in India, "World Cotton Research Conference". 7-11 November, 2011. Mumbai.pp.450-453.

Arshad, M., Maqsood, M., Wajid, A., Hussain, K., Aslam, M. and Ibrahim, M. (2007). Response of growth, yield and quality of different cotton cultivars to sowing dates. Pak. J. Agric., 44 (2).118122.

Bozbek, T., Sezener, V., and Unay, A. (2006). The effect of sowing date and plant density on cotton yield. Journal of
Agronomy, 5(1): 122-125.

Brar, A. S. and Singh, T. H., (1994). Reappraisal of the optimum sowing period for American cotton in Punjab: Effect on yield and yield components. Journal of Indian Society for Cotton Improvement, 19 (2): 157-160.

Brar, A. S., Rajinder Singh, and Singh, T. H., (1990).A note on the performance of Hirsutum cotton varieties under different sowing dates and spacing. Indian Society for Cotton Improvement Journal, 15 (1): 47-48.

Brar, A. S., Thind, R. J. S., Kular, J. S. and Singh, T. H., (1996). Effect of sowing time, spacing and nitrogen levels on upland cotton cultivars in Punjab. Journal of Indian Society for cotton improvement, 21 (1): 41-44.

Buttar, G. S., Mahay, R. K. and Aggarwal, N., (2005). Effect of sowing dates, planting methods and irrigation scheduling on the growth and yield of American Cotton. Journal of Cotton Research and Development, 19 (2): 213-215.

Dhoble, M. V., Giri, D. G., Patil, V. D. And Pawar, B. R., (1988).Productivity of cotton varieties as influenced by sowing dates and plant densities. Journal of Maharashtra Agricultural Universities, 13(2): 177-179.

Hanuman Prasad, Nehra, P. L., Gothwal, D. K. And Harphool Singh, (2000), Effect of date of sowing and spacing on seed cotton yield. Journal of Cotton Research and Development, 14 (2): 232-234.

Koraddi, V. R., Basavanna, P., Guggari, A. K., and Kamath, K. S., (1992). Response of rainfed cotton to sowing dates, spacing and fertilizer levels. Journal of Maharashtra Agriculture Universities, 17 (1):69-72.

Nehra, P. L. and Matish Chandra, (2001).Performance of Hirsutum cotton 
under different sowing dates and spacing. Journal of Cotton Research and Development, 15 (2): 147-150.

Singh, I. and Nagda, B. L. (1996).Effect of sowing date, spacing and nitrogen level on upland cotton. Indian Journal of Agricultural Sciences.66(5): 293-4.
Srinivasan, G., (2001). Response of summer irrigated cotton (Gossypium hirsutum) to sowing dates and nutrient management practices. Indian Journal of Agronomy, 46 (3): 552-556.

\section{How to cite this article:}

Vibha Tak, Vyas Pandey and Parmar, P.K. 2020. Impact of Variety and Date of Showing on Growth Performance of Bt-Cotton in Middle Gujarat Conditions. Int.J.Curr.Microbiol.App.Sci. 9(12): 1208-1213. doi: https://doi.org/10.20546/ijcmas.2020.912.148 